Ann. Génét. Sél. anim., I979, 11 (2), II5-I20.

\title{
A new autosomal translocation in "Alpine grey cattle"*
}

\author{
Annamaria DE GIOVANNI, G. SUCCI, L. MOLTENI et M. CASTIGLIONI \\ Istituto di Zootecnia Generale \\ Facoltà di Agraria \\ Università degli Studi \\ Milano-Italia
}

\section{Summary}

In the cytogenetical research experiments at present carried out in Italian cattle breds which are in way of numerical decrease, we have taken into consideration a sample number of 50 bulls of the "Grigia Alpina breed", chosen out of a group coming from an A.I. Centre and from those which were selected for reproduction purposes at the Pure Breed Show.

Five bulls resulted to be carriers of a new autosomal translocation involving two of the smallest chromosomes.

On the basis of the results obtained by need of measurements and the application of banding, we are of the opinion the translocation concerns the chromosomes of the pairs 25 and 27 .

Two of the translocation carriers, kept at an A.I. Centre have never given semen suitable for freezing purposes.

\section{Introduction}

Starting from the famous translocation I $/ 29$ discovered by Gustavsson and ROCKBORN in 1964 in the Swedish Red and White breed, a considerable number of other chromosomal anomalies have been discovered since then in various parts of the world and in several different breeds of cattle. The translocation $1 / 29$ seems to be the most widespread (PoPEscu, r977), and even in our country cattle breeds seem to be particularly affected. It is to be found in the Romagnola breed at the level of heterozygous state equivalent to $28.8 \mathrm{p}$. IOO (DE GrovanNI and MoLTENI, I976). It is also met with other breeds such as Chianina, Marchigiana and Modicana (SuCci and De Grovanni, I976; Mor,Teni et al., I977).

(*) Research supported by the Italian National Research Council (C.N.R.) within the Program "Defense of Animal Genetic Resources ".

This paper has been presented at the "First International Symposium of Research on Cytogenetics and Disease Resistence in Animals and man ", Vienna, 17-19 May 1979. 
However other anomalies have been discovered and identified either by means of banding methods or by measuring the relative length of the chromosomes in question. POPESCU's scientific paper (1977) explains in great depth all the anomalies discovered up till now in the Bos taurus I. To these abnormalities one must add the translocation $\mathrm{I} 4 / 20$ which was more recently identified by LoGUE and HARVEy (I978).

We present a new type of Robertsonian translocation in which the chromosomes involved are identified by measurements and banding studies.

\section{Materials and methods}

In the research program of the Italian National Research Council (C.N.R.) "Defense of animal genetic resources" meant to identify the chromosomal complement of various Italian cattle breeds in way of exstinction, we have examined $5^{\circ}$ bulls, belonging to the Alpine Grey (Grigia Alpina) breed". Out of the group

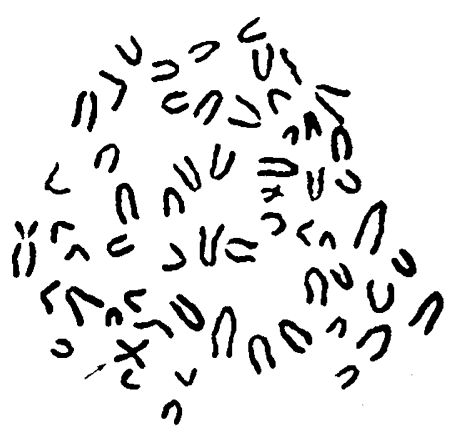

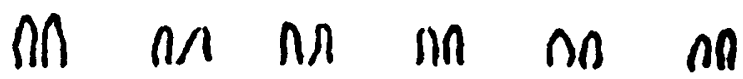

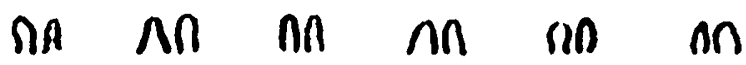

nn nn na na na na

nn nn nn -n nn nn

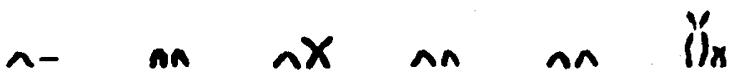

FIG. I. - Metaphase and karyotype of a cell,

stained with standard method carrying the 25/27 translocation (arrow).

Métaphase et caryotype d'une cellule colorée avec la méthode standard et portant la translocation $25 / 27$ (flèche). 
some were chosen by the Zootechnic Commission of the Herd Book to be destined for the Progeny test and the rest were selected at the Bolzano Pure Breed Show as Prime specimens of their breed. The latter group were set aside in various breeding stations in Alto Adige for reproduction purposes.

The microscopic specimens were obtained by culture of leucocytes from the peripheral blood according to the method of MoorheAD et al. (I960) slightly modified.

The chromosomes involved in the translocation were identified by the $R$ banding method using BUDR, and Orange Acridine staining (POPESCU, 1975). The densitometric profiles were obtained with a LEITZ MPV II microphotometer.

The idiogram was constructed on the basis of ro cells from all the heterozygous animals.

The C-bands were obtained by Summer's method (I972) modified by Popescu (I974).

\section{Results}

The karotype of 5 animals evidenced the normal number of chromosomes reduced to 59 , due to the presence of a small metacentric chromosome, whose centrometric index is $47.44 \pm 2.57$, obtained by fusing 2 chromosomes of small dimensions (fig. I).

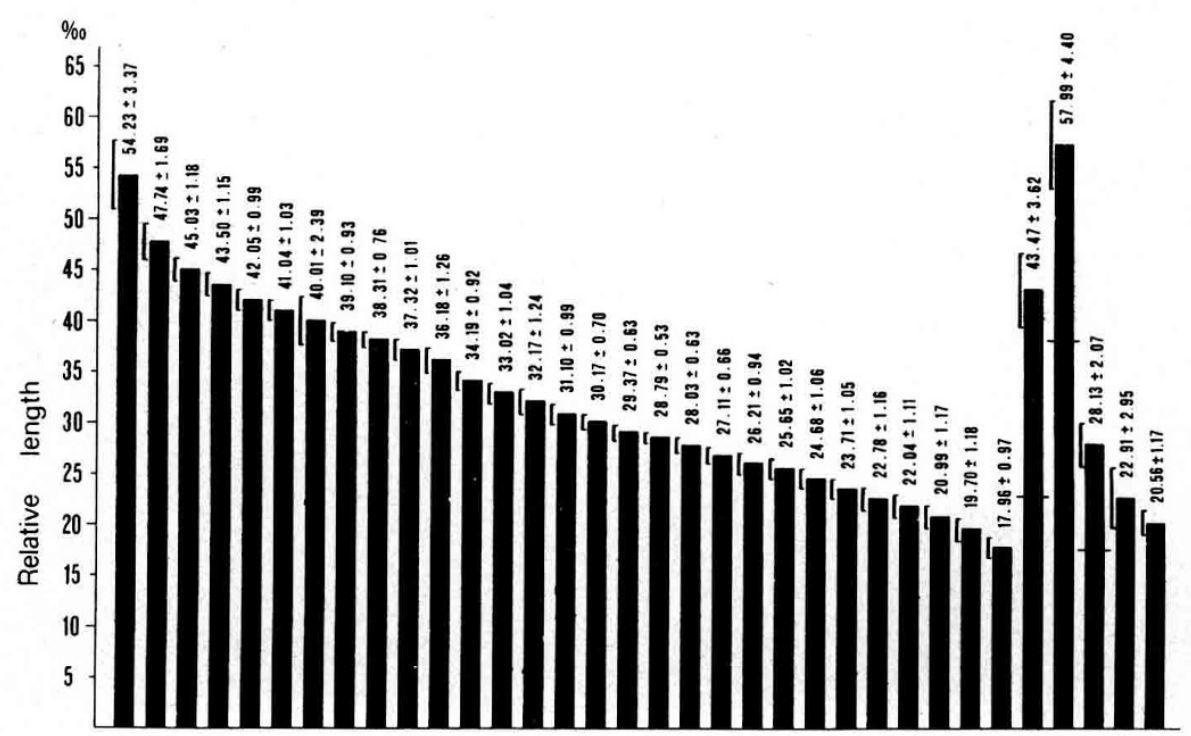

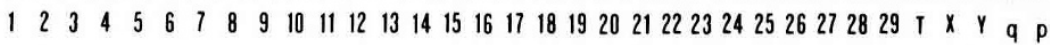

FIG. 2. - Idiogram of a caryotype with the 25/27 translocation. $T$ : translocated chromosome; $\mathrm{p}$ : little arm; $\mathrm{q}$ : long arm.

Idiogramme d'un caryotype porteur de la translocation $25 / 27$. $T$ : chromosome transloqué; $\mathrm{p}$ : petit bras; $\mathrm{q}$ : long bras. 


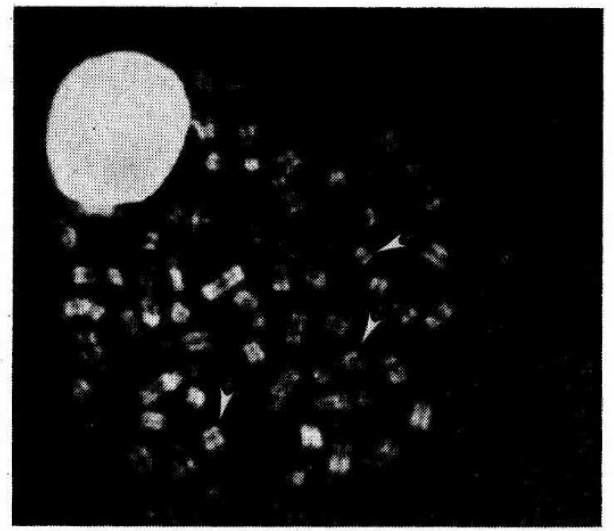

FIG. 3. - Metaphase of a cell carrying the 25/27 translocation, obtained after incorporation of $B U D R$ and acridine orange staining. Arrows indicate the fused chromosome and the free chromosomes 25 and 27.

Métaphase d'une cellule porteuse de la translocation 25/27 obtenue après incorporation de BUDR et de colorant acridine orange. Les flèches indiquent le chromosome fusionné et les chromosomes 25 et 27 libres.
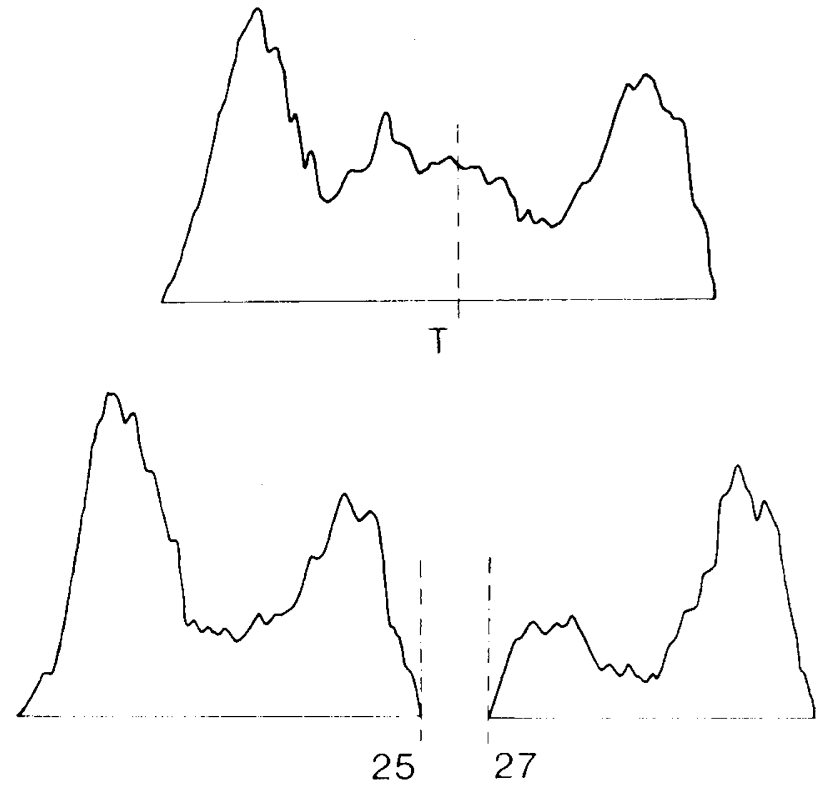

FIG. 4. - Microdensitometric profiles of fused chromosome and free chromosomes 25 and 27.

Profils microdensitométriques du chromosome fusionné et des chromosomes 25 et 27.

Moreover in one of the carriers, probably co-twin of a free-martin, were found only female cells. Four of the 5 carrier bulls were related to each other (they had a 3 rd generation ancestor in common), whereas the 5 th had no close connection with the others. 
From the measurement idiogram it may be seen that the long arm is within the range of the pairs $2 \mathrm{I}-28$ and the short one within the range of the pairs $25-28$ (fig. 2).

After R-band labelling, the long arm of the abnormal chromosome showed the same pattern as the free chromosome 25 and the short one as the free chromosome 27, according to Gustavsson and HAGELTORN (1976) (fig. 3).

With the use of the LEITZ MPV II microphotometer a sketch was made of the banded chromosomal profiles. In spite of the small number of metaphases we were able to examine, due to the impossibility of being connected with a suitable computer, non-the-less, we were able to confirm that the chromosomes involved in the translocation are those belonging to the pairs 25 and 27 (fig. 4).

The fused chromosome in cells treated by C-banding method, appears as carrying a single constitutive heterochromatin block on its long arm (fig. 5).

Up till now we have only been able to study the sexual behaviour and semen picture of 2 out of the 5 mentioned bulls which were brought to an Artificial Insemination Centre.

Apart from the 2 bulls'poor " libido", the few ejaculations presented, seemed to be of bad quality and insufficient and not suitable for freezing purposes. On the contrary all the bulls belonging to the same bred that were present in the same Centre have always supplied spermatic material of good quality and quantity and suitable for freezing purposes. In the light of these first comments, we intend to carry out the study of this new translocation. We intend to study the meiosis of male translocation heterozygotes with the aim of pointing out the presence of the trivalent and, if that is the case, of cells with unbalanced karyotypes in the second meiotic metaphases.

We intend also to go into the study of fertility in greater depth by keeping a greater number of the translocation carriers under control.

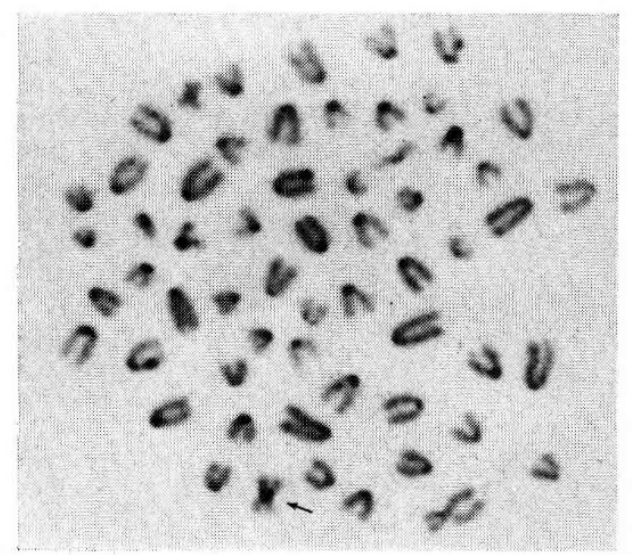

FIG. 5. - Metaphase of a C-bands treated cell carrying the 25/27 translocation (arrow). Métaphase en bandes $C$ d'une cellule portant la translocation 25 !27 (fièche). 


\section{Résumé}

\section{Une nouvelle translocation autosomale chez le bétail Gris des Alpes}

Dans le cadre d'un programme de recherche portant sur les races bovines italiennes en voie de disparition, une étude cytogénétique sur 50 taureaux de race Grise des Alpes a été entreprise. Cinq animaux ont été trouvés porteurs d'une nouvelle translocation robertsonienne.

Par la méthode des bandes $\mathrm{R}$ nous avons constaté que la translocation implique les chromosomes 25 et 27 . La semence des deux animaux porteurs de cette anomalie n'a jamais pu être congeléc.

\section{Riassunto}

\section{Nuova traslocazione autosomica nella razza Grigia Alpina}

Nell'ambito delle ricerche volte ad individuare citogeneticamente le razze bovine italiane in via di estinzione, abbiamo preso in esame 50 tori appartenenti alla razza Grigia Alpina. I soggetti sono stati scelti tra quelli presenti in un Centro di Fecondazione Artificiale e traquelli che, giudicati migliori alle Aste stagionali della razza, tenutesi a Bolzano, venivano destinati alla riproduzione.

5 tori sono risultati portatori di una nuova traslocazione derivata dalla fusione di due tra $i$ più piccoli autosomi che, mediante misurazioni e bandeggio, sono risultati appartenere alle coppie 25 e 27.

Due dei soggetti portatori della traslocazione non hanno finora dato materiale spermatico adatto al congelamento.

\section{References}

De Grovanni Annamaria and Molteni L., 1976. Ulteriore indagine citogenetica sulla razza bovina Romagnola. Nota I : Nuovi casi di fusione centrica. Atti Soc. It. Sci. Vet., 30, 479-481.

Gustaysson I. and Rockborn G., 1964. Chromosome abnormality in three cases of lymphatic leukaemia in cattle. Nature (Lond.), 203, 990.

Gustavsson I. and Hageltorn M., i976. Staining technique for definite identification of individual cattle chromosomes in routine analysis. J. Heved., 67, $175^{-1} 78$.

Logue D. N. and HARVEY M. J. A., 1978. A I4/20 Rodertsonian translocation in Swiss Simmental catte. Res. Vet. Sci., 25, 7-12.

Molteni L., Succi G. and De Giovanni Annamaria, i977. Étude cytogénétique sur certaines races bovines italiennes en voie de diminution ou menacées de disparition. III e Coll. de Cytogénét. anim. domes., Jouy-en-Josas (France) 3I mai-2 juin 1977. In Ann. Génét. Sél. anim., 9, 534 .

Moorhead P. S., Nowell P. C., Mellman W. J., Battips D. M. and Hungerford D. A., I96o. Chromosome preparation of leucocytes cultured from human peripheral blood. Exp. Cell Res., 20, 6г 3-6г6.

Popescu C. P., I974. Étude du caryotype bovine par une nouvelle méthode cytogénétique : les bandes C. Ier Congr. Mond. Génét. appl. à l'élev., Madrid, 7-I I octobre I974, 3, I 59-I 64.

Popescu C. P., 1975. Essai d'identification des chromosomes bovins (Bos taurus L.) à l'aide du marquage au 5-bromodeoxiuridine (BUDR). II e Coll. Europ. Cytogénét. Anim. dom. Giessen, 29-30 septembre 1975, 59-64.

Popescu C. P., I977. Les anomalies chromosomiques des bovins (Bos taurus L.). État actuel des connaissances. III Coll. Cytogénét. Anim. domes. Jouy-en-Josas (France), 3 I mai-2 juin 1977. In Anr. Génét. Sél. anim., 9, 463-470.

Succi G. and De Giovanni Annamaria, 1976.Sulla presenza della traslocazione $1 / 29$ in alcune razze bovine italiane. Atti Soc. It. Sci. Vet., 30, 486-489.

SUMNER A. T., I972. A simple technique for demonstrating centromeric heterochromatin. Exp. Cell Res., 75, 304-306. 